\title{
Study of the maturation of grapes (Vitis vinifera L.) grown in Dois Vizinhos, Paraná
}

\author{
Evolução da maturação de uvas finas (Vitis vinifera L.), no \\ município de Dois Vizinhos - Paraná ${ }^{1}$
}

\author{
Gener Augusto Penso ${ }^{2 *}$; Idemir Citadin ${ }^{3}$; Luana Aparecida Castilho Maro ${ }^{3}$; \\ Silvia Scariotto ${ }^{4}$; Alyne Chicoki ${ }^{5}$; Rodrigo Ambrosio ${ }^{5}$
}

\begin{abstract}
The edaphoclimatic conditions in Southwest Parana differ from those in traditional wine-growing regions and have a major influence on the organoleptic characteristics of the grapes. Studies of grape maturation under these conditions may enable us to time the supply of raw materials for the elaboration of differentiated wines. This study aimed to quantify the ripening components of the grape cultivars Cabernet Sauvignon, Merlot, Tempranillo, and Sangiovese grapes grown in Dois Vizinhos, PR, during the harvest seasons of 2008/2009 and 2011/2012. The grapevines were performed according to the espalier system and grafted on rootstock R110 ('Cabernet Sauvignon' and 'Merlot') and Paulsen 1103 ('Tempranillo' and 'Sangiovese'). The ripening of the grapes was monitored every ten days from the beginning of ripening (verasion) until harvest. The following variables were evaluated: mass and diameter of berries, total soluble solids (TSS), $\mathrm{pH}$, titratable acidity (TTA), total sugars, estimated alcohol content, anthocyanins, and flavanols. Sangiovese berries showed the greatest weight and diameter in the two years. The TSS was higher in the second year of evaluation for Cabernet Sauvignon and Tempranillo grapes. The $\mathrm{pH}$ decreased from the first year to the second for all cultivars. There were no significant differences in ATT among the cultivars. A higher content of flavanols was observed during the first growing season of study than during the second. Tempranillo grapes showed the highest concentration of anthocyanins during both growing seasons. Not all cultivars had enough acidity to permit wine stability and guard time. None of the cultivars required the chaptalization of must, presenting good potential of alcohol production.
\end{abstract}

Key words: Wine, European grapes, terroir

\section{Resumo}

As particularidades edafoclimáticas do Sudoeste paranaense diferem das tradicionais regiões de cultivo da videira e exercem grande influência nas características organolépticas das bagas. Estudos sobre a evolução da maturação de uvas nessas condições podem viabilizar o fornecimento de matéria-prima para a elaboração de vinhos diferenciados. Objetivou-se quantificar os componentes da maturação de uvas das cultivares Cabernet Sauvignon, Merlot, Tempranillo e Sangiovese cultivadas no município de Dois Vizinhos - PR, nas safras de 2008/2009 e 2011/2012. As videiras foram conduzidas em espaldeira e enxertadas sobre o porta-enxerto R110 ('Cabernet Sauvignon' e 'Merlot') e Paulsen 1103

\footnotetext{
${ }^{1}$ Este trabalho é parte do trabalho de conclusão de curso do primeiro autor, financiado pela Universidade Tecnológica Federal do Paraná, UTFPR, Campus Pato Branco, Pato Branco, PR, Brasil.

2 Discente do Curso de Agronomia, UTFPR, Campus Pato Branco, Pato Branco, PR, Brasil. E-mail: generpenso@gmail.com

${ }^{3}$ Eng $^{\text {os }}$ Agr ${ }^{\text {os }}$, Profs. Drs., UTFPR, Campus Pato Branco, Pato Branco, PR. E-mail: idemir@utfpr.edu.br; luanamaro@utfpr.ed.br

${ }^{4}$ Eng $^{\text {a }}$ Agra , M.e Assistente de Pesquisa, Pato Branco, PR, Brasil. E-mail: silviascariotto@yahoo.com.br

${ }^{5}$ Eng $^{\text {os }}$ Agros , Discentes do Curso de Mestrado em Agronomia, UFPR, Curitiba, PR, Brasil. E-mail: alyne.chicock@yahoo.com.br; rodrigoambrosioufpr@gmail.com

* Author for correspondence
} 
('Tempranillo' e 'Sangiovese'). A evolução da maturação das uvas foi acompanhada a cada dez dias a partir do início da maturação (verasion) até a colheita. As seguintes variáveis foram avaliadas: massa e diâmetro médio das bagas, teor de sólidos solúveis totais (SST), pH, acidez total titulável (ATT), açúcares totais, álcool provável, antocianinas e flavonóis. Bagas da cv. Sangiovese apresentaram maior massa e diâmetro médio nos anos avaliados. Os teores de SST foram maiores no segundo ano de avaliação para as cvs. Cabernet Sauvignon e Tempranillo. O pH sofreu redução do primeiro ano para o segundo de avaliação, para todas as cultivares. Não houve diferenças significativas na ATT entre as cvs. A maior concentração de flavonóis foi obtida no primeiro ciclo de estudo. A cv. Tempranillo apresentou concentração mais elevada de antocianinas nos dois anos avaliados. Todas as cultivares não apresentam acidez total suficiente para permitir ao vinho estabilidade e tempo de guarda. Todas as cvs. dispensam a chaptalização do mosto tendo boa produção de álcool provável.

Palavras-chave: Vinho, uvas europeias, terroir

\section{Introduction}

Viticulture has high socioeconomic importance in the Brazilian fruit-production sector. It generates a large number of jobs and relevant business opportunities with regard to the production of table grapes and grapes for use in the processing industries. In 2012, approximately 1.45 million tons of grapes were produced across different regions of Brazil. However, the greatest contribution was from the South of Brazil, which accounted for $68 \%$ of the total grapes produced (IBGE, 2013).

The North ofParaná has recognized importance in the production of table grapes and wines with strong aromas characteristic from American cultivars (Vitis labrusca). The grape production in Southwest of Paraná is primarily intended for the elaboration of table wine and juices, among other products (SATO; ROBERTO, 2008). This emerging grape-producing region has a plantation area of approximately 1,000 hectares, totaling approximately 12,000 tons, according to data from SEAB-DERAL (2011). The expansion of viticulture in the Southwest region of Paraná may help to meet the increasing demand for high-quality Brazilian wines.

The study of grape maturity is extremely important to determine the quality of the wines produced. It is during this period that the synthesis, degradation, and/or translocation of desirable compounds occurs in the grapes, and these compounds include sugars, terpenes, anthocyanins, tannins, and organic acids (CONDE et al., 2007).

Grape composition is defined by the interaction between climate, soil, rootstock, cultivar, and other agronomic parameters, which together determine the terroir of a wine-growing region (ZSÓFI et al., 2009). Thus, the knowledge of the factors involved in the production and quality of each cultivars will help define strategies that promote higher expression of desirable characteristics. Such characteristics may confer differentiation and originality to the wines elaborated from grapes produced in the Southwest region of Paraná.

The aim of this study was to quantify the different components during the maturation process of Cabernet Sauvignon, Merlot, Tempranillo, and Sangiovese grapes grown in Dois Vizinhos, PR, from the beginning of maturation until harvest to verify whether they meet the requirements for the production of high-quality wines.

\section{Materials and Methods}

This study was carried out in a commercial vineyard located in Dois Vizinhos, Paraná $\left(25^{\circ} 51\right.$ ' $\mathrm{S}, 53^{\circ} 06^{\prime} \mathrm{W}$ with an average altitude of $568 \mathrm{~m}$ ). The climate in this region is humid subtropical, and the average annual rainfall is 1,800-2,000 $\mathrm{mm}$ (CAVIGLIONE et al., 2000). The soil is an Umbric Distroferric Red Nitosoil, clayey texture, subtropical forest evergreen phase, wavy relief, associated with Cambisoil (BHERING et al., 2008). The rainfall and temperature in this region were monitored during the study period to determine the influence of these parameters on grape quality and consequently on the wine produced (Figure 1). 
Figure 1. Mean maximum and minimum temperatures and rainfall from December to April in 2008/2009 and 2011/2012. UTFPR Câmpus Pato Branco, 2012.

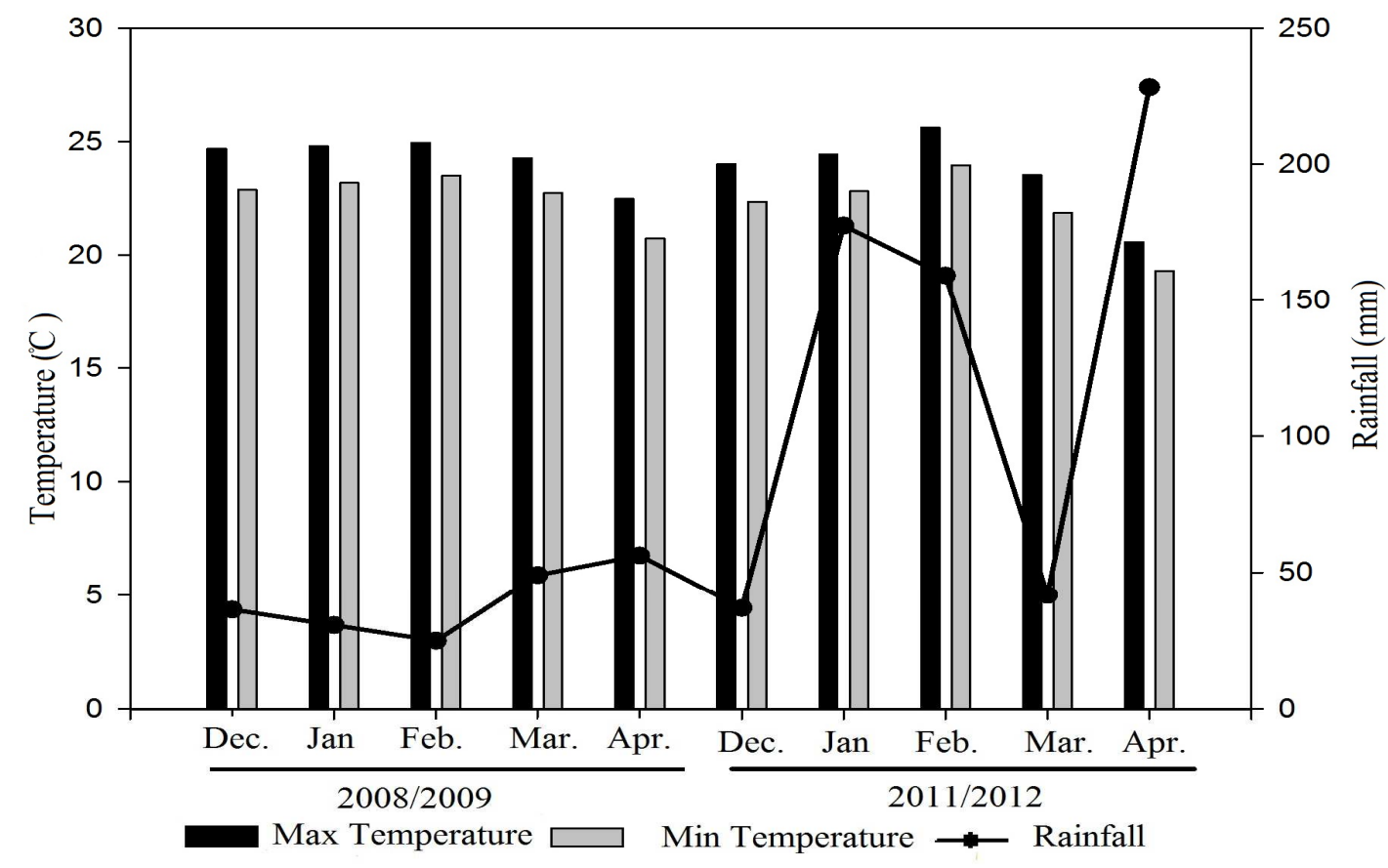

Source: Elaboration of the authors.

Plants were conducted according to the espalier system, with a spacing of $2.5 \mathrm{~m}$ between plants and $3 \mathrm{~m}$ between rows with approximately 40 plants per cultivation line for Merlot and Cabernet Sauvignon grapes and $2 \mathrm{~m}$ between plants and $3 \mathrm{~m}$ between rows with approximately 30 plants per cultivation line for Sangiovese and Tempranillo grapes. Merlot and Cabernet Sauvignon (planted in 2003) are clones of IS5 grafted onto the rootstock R110, whereas Sangiovese and Tempranillo (planted in 2005) are clones of VCR 49 grafted onto the rootstock Paulsen 1103.

The grapes were collected from the veraison period until they were completely ripened, which was between $12 / 16 / 2008$ and $02 / 12 / 2009$ in the $2008 / 2009$ growing season, and 12/22/2011 and $02 / 13 / 2012$ during the $2011 / 2012$ growing season, with collections taking place every ten days throughout both cycles. For each cultivar, four cultivation lines were collected, with samples of 100 grapes berries being collected from each line (two grapes berries per plant). Then, the samples were separated into three groups of 25 grapes berries, in the laboratory discarding $1 / 4$ of the sample, giving 12 replications per cultivar.

The samples were transported to the Fruticulture Laboratory at the Federal University of Technology - Paraná (UTFPR), Câmpus Pato Branco and the following physical properties were determined: mean grape berries mass was weighed using an analytical balance, expressing the data in grams (g), and the average grape berries diameter was measured using a digital pachymeter and was expressed in millimeters ( $\mathrm{mm})$.

The grapes berries used in each experiment were then crushed manually to extract the must, without separating the seeds. The extract was then used to assess the following variables: $\mathrm{pH}$, total soluble solids (TSS) by refractometry and expressed in ${ }^{\circ}$ Brix, and total titratable acidity (TTA) by titration with $0.1 \mathrm{~N}$ sodium hydroxide, with the result being expressed in meq tartaric acid $\mathrm{L}^{-1}$, according to 
the guidelines stated by the Adolfo Lutz Institute (2008). The anthocyanins and flavonols were quantified using the process described by Lees and Francis (1972). The results were expressed in $\mathrm{mg}$ of anthocyanins and/or flavonols per $100 \mathrm{~g}^{-1}$ of peel.

The expected alcohol content was estimated from the content of total soluble solids according to the methodology proposed by Jaulmes and Espezel (1935).

The experimental design used was a randomized block arranged in a $2 \times 4$ factorial with factor A formed by the growing seasons (2008/2009 and 2011/2012) and factor B by the cultivars (Cabernet Sauvignon, Merlot, Tempranillo, and Sangiovese).

The data were initially subjected to the ShapiroWilk test to verify the normality of the data. When a normal distribution was not found, the data were transformed using $\sqrt{(x+1)}$. Analysis of variance (ANOVA) was calculated, and means were compared using Tukey test $(p=0.05)$. The analyses were performed using the program Genes (CRUZ, 2013).

\section{Results and Discussion}

Under the study conditions (Figure 1), there was an increase in the total mass of Merlot, Tempranillo, and Sangiovese grape berries until January $25^{\text {th }}$ during both growing seasons, with little variation during the following samples. However, for Cabernet Sauvignon, this increase in mass occurred until January $29^{\text {th }}$ and January $31^{\text {st }}$, which may have been due to this cultivar having a delayed cycle
(Figure 2). For Merlot and Tempranillo, the grape berries mass decreased in the final samples during both growing seasons, which may indicate overripening. The mass loss is due to the interruption of the transport of nutrients to the berry along with the occurrence of drought causing desiccation and consequent weight loss (GUERRA; ZANUS, 2003).

Cabernet Sauvignon, Merlot, and Tempranillo showed very similar results in both seasons. Sangiovese had a greater average mass of grape berries during both growing seasons (Table 1). The greater grape berries mass is an intrinsic characteristic of this cultivar as described by Gil and Pszczólkwski (2007), who classified the size of the Sangiovese grape berries as medium to large. The seeds are also large and contribute to higher weight of the berries. Cabernet Sauvignon and Merlot grape berries are smaller, and our results are consistent with those obtained by Rizzon and Mielle (2003) in several harvests in the Serra Gaúcha region, who found the grape berries mass to be consistently less than $2 \mathrm{~g}$.

The grape berries mass during maturation is correlated with sugar accumulation, availability of water in the soil and atmosphere, and the number of seeds. Smaller fruits ultimately release larger quantities of minerals including potassium, calcium, and magnesium, which greatly influence $\mathrm{pH}$ and total titratable acidity. Smaller grapes berries also affect the organoleptic characteristics of the wine due to the release of high quantities of tannins, which are present in large concentrations in the seeds and may turn the wine astringent (CONDE et al., 2007). 
Figure 2. Changes in mass during maturation of Cabernet Sauvignon (A), Merlot (B), Tempranillo (C), and Sangiovese (D) grape berries in Dois Vizinhos, PR during the 2008/2009 and 2011/2012 growing seasons. UTFPR Câmpus Pato Branco, 2012.
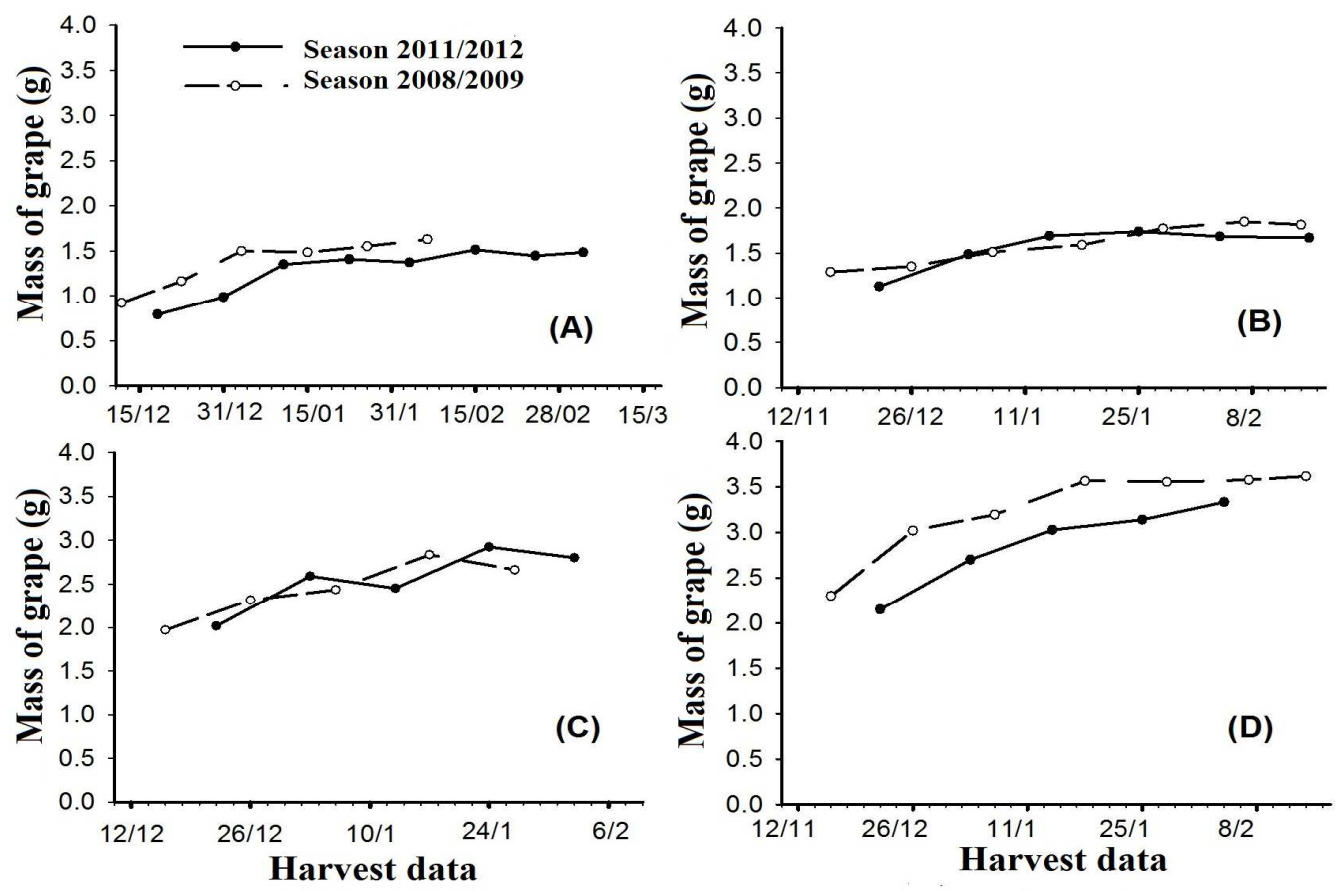

Source: Elaboration of the authors.

Table 1. Average mass of grape berries $(\mathrm{g})$, grape berries diameter $(\mathrm{mm}), \mathrm{pH}$ of must, total soluble solids $\left({ }^{\circ} \mathrm{Brix}\right)$, estimated alcohol content ( $\% \mathrm{v} / \mathrm{v})$, total titratable acidity (meq L $\mathrm{L}^{-1}$ of tartaric acid), flavonoids $\left(\mathrm{mg} 100 \mathrm{~g} \mathrm{~g}^{-1}\right.$ of peel), anthocyanins (mg $100 \mathrm{~g}^{-1}$ of peel) of Vitis vinifera produced in Dois Vizinhos during 2008/2009 and 2011/2012 growing seasons. UTFPR Câmpus Pato Branco, 2012.

\begin{tabular}{|c|c|c|c|c|c|c|}
\hline \multirow[b]{2}{*}{ VARIABLES } & \multirow[b]{2}{*}{ Growin seasons } & \multicolumn{4}{|c|}{ CROPS } & \multirow[b]{2}{*}{$\mathrm{CV}}$. \\
\hline & & Cabernet Sauvignon & Merlot & Tempranillo & Sangiovese & \\
\hline \multirow{2}{*}{$\begin{array}{c}\text { Grape berries mass } \\
(\mathrm{g})\end{array}$} & $2008 / 2009$ & $1.63 \mathrm{Ac}$ & $1.85 \mathrm{Ac}$ & $2.67 \mathrm{Ab}$ & $3.56 \mathrm{Aa}$ & \multirow{2}{*}{5.33} \\
\hline & $2011 / 2012$ & $1.49 \mathrm{Ac}$ & $1.65 \mathrm{Ac}$ & $2.82 \mathrm{Ab}$ & $3.33 \mathrm{Ba}$ & \\
\hline \multirow{2}{*}{$\begin{array}{l}\text { Grape berries diameter } \\
\qquad(\mathrm{mm})\end{array}$} & $2008 / 2009$ & $13.56 \mathrm{Aa}$ & $14.51 \mathrm{Aa}$ & $15.81 \mathrm{Aa}$ & $17.92 \mathrm{Aa}$ & \multirow{2}{*}{1.08} \\
\hline & $2011 / 2012$ & $12.70 \mathrm{Bb}$ & $13.14 \mathrm{Bb}$ & $15.88 \mathrm{Aa}$ & $16.52 \mathrm{Bb}$ & \\
\hline \multirow{2}{*}{$\mathrm{pH}$ of must } & $2008 / 2009$ & $3.76 \mathrm{Aa}$ & $4.21 \mathrm{Aa}$ & $4.04 \mathrm{Aa}$ & $4.49 \mathrm{Aa}$ & \multirow{2}{*}{0.65} \\
\hline & $2011 / 2012$ & $3.54 \mathrm{Ba}$ & $3.55 \mathrm{Ba}$ & $3.42 \mathrm{Ba}$ & $3.39 \mathrm{Ba}$ & \\
\hline \multirow{2}{*}{ TSS $\left({ }^{\circ}\right.$ Brix $)$} & $2008 / 2009$ & $18.07 \mathrm{Bc}$ & $21.03 \mathrm{Aa}$ & $19.40 \mathrm{Bb}$ & $20.50 \mathrm{Aa}$ & \multirow{2}{*}{2.42} \\
\hline & $2011 / 2012$ & $18.79 \mathrm{Ab}$ & $20.90 \mathrm{Aa}$ & $20.62 \mathrm{Aa}$ & $18.24 \mathrm{Bb}$ & \\
\hline \multirow{2}{*}{$\begin{array}{l}\text { Estimated alcohol } \\
\text { content }(\%(\mathrm{v} / \mathrm{v}))\end{array}$} & $2008 / 2009$ & $10.27 \mathrm{Ac}$ & $12.22 \mathrm{Aa}$ & $11.10 \mathrm{Bb}$ & $11.87 \mathrm{Aa}$ & \multirow{2}{*}{2.65} \\
\hline & $2011 / 2012$ & $10.72 \mathrm{Ab}$ & $12.10 \mathrm{Aa}$ & $11.92 \mathrm{Aa}$ & $10.37 \mathrm{Bb}$ & \\
\hline \multirow{2}{*}{$\begin{array}{l}\text { Total titratable acidity } \\
\text { (TTA) (meq L }{ }^{-1} \text { of } \\
\text { tartaric acid) }\end{array}$} & $2008 / 2009$ & $49.25 \mathrm{Bb}$ & $36.25 \mathrm{Bc}$ & $61.00 \mathrm{Ba}$ & $44.00 \mathrm{Bb}$ & \multirow[b]{2}{*}{6.05} \\
\hline & $2011 / 2012$ & $56.66 \mathrm{Ac}$ & $69.58 \mathrm{Ab}$ & 74.58 Aab & $79.51 \mathrm{Aa}$ & \\
\hline \multirow{2}{*}{$\begin{array}{c}\text { Flavonoids (mg } 100 \mathrm{~g}^{-1} \\
\text { of peel) }\end{array}$} & $2008 / 2009$ & $146.61 \mathrm{Aa}$ & $109.10 \mathrm{Abc}$ & $127.15 \mathrm{Aab}$ & $89.29 \mathrm{Ac}$ & \multirow{2}{*}{11.88} \\
\hline & $2011 / 2012$ & $55.80 \mathrm{Bb}$ & $73.91 \mathrm{Bab}$ & $90.99 \mathrm{Bb}$ & $68.80 \mathrm{Bab}$ & \\
\hline \multirow{2}{*}{$\begin{array}{c}\text { Anthocyanins (mg } 100 \\
\mathrm{~g}^{-1} \text { of peel) }\end{array}$} & $2008 / 2009$ & $344.37 \mathrm{Aa}$ & $194.94 \mathrm{Aba}$ & $388.99 \mathrm{Aa}$ & $137.10 \mathrm{Ac}$ & \multirow{2}{*}{9.89} \\
\hline & $2011 / 2012$ & $133.39 \mathrm{Bb}$ & $156.64 \mathrm{Bb}$ & $332.63 \mathrm{Bb}$ & $151.53 \mathrm{Ab}$ & \\
\hline
\end{tabular}

Averages followed by the same uppercase letters in columns and same lowercase letters in rows do not differ significantly by Tukey's test $(p \leq 0.05)$. The data for diameter and $\mathrm{pH}$ were transformed using $\sqrt{(x+1)}$

Source: Elaboration of the authors. 
The mean diameter of grape berries in all cultivars increased from verasion until harvest, with the increase being greatest for Cabernet Sauvignon and Tempranillo (Figure 3). For Tempranillo, the results were similar during both growing seasons
(Table 1). For Cabernet Sauvignon and Merlot, there was a significant difference between both growing cycles, with the best results being obtained in the 2008/2009 growing season.

Figure 3. Changes in grape berries diameter during maturation of Cabernet Sauvignon (A), Merlot (B), Tempranillo (C), and Sangiovese (D) grapes in Dois Vizinhos, PR during 2008/2009 and 2011/2012 growing seasons. UTFPR Câmpus Pato Branco, 2012.
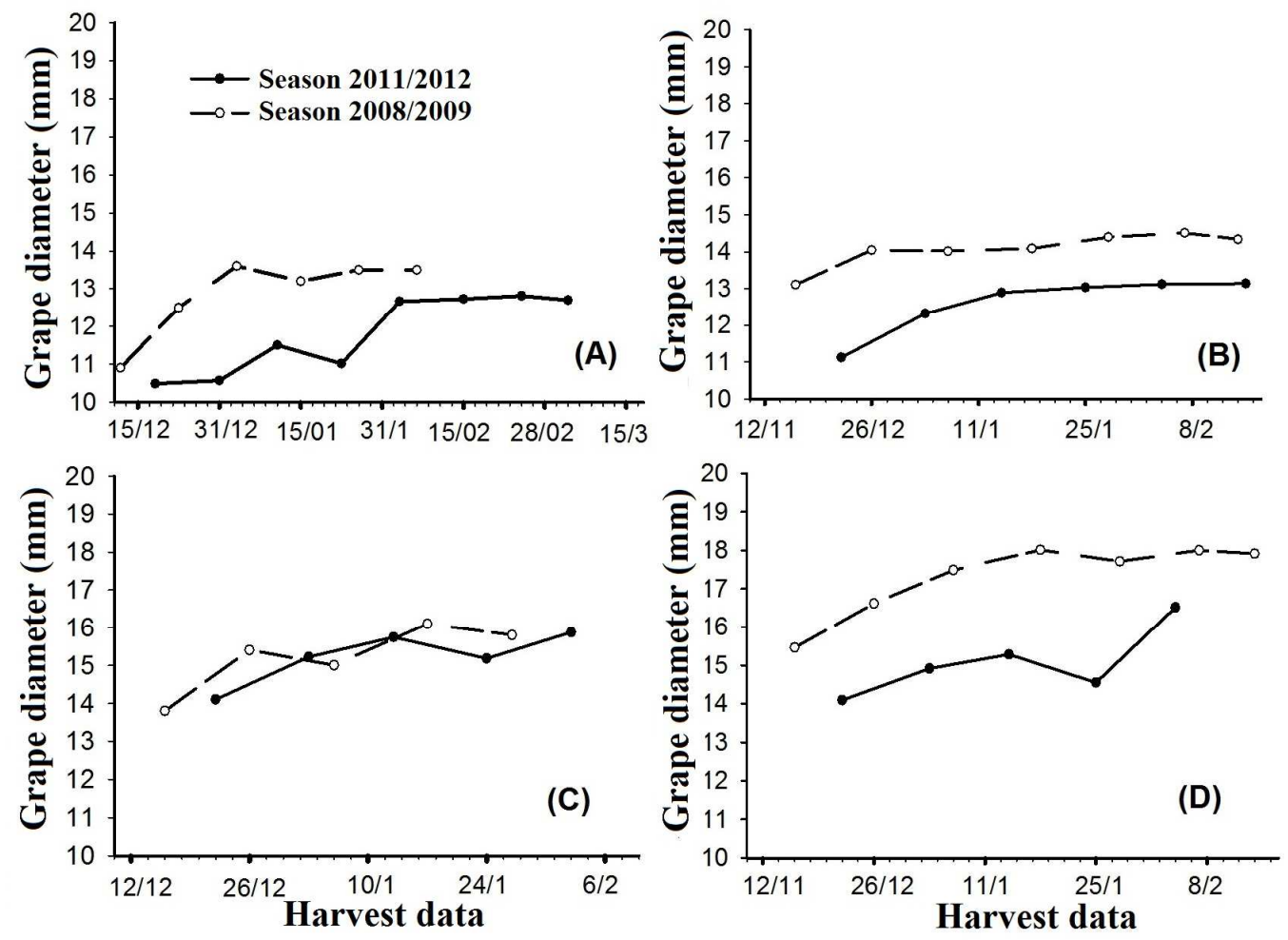

Source: Elaboration of the authors.

Grape berries diameter is influenced by several factors including: the genetic characteristics of the cultivar, hormonal equilibrium, the amount of water absorbed by the plant, and the concentration of sugar. According to Dias (2006), temperature influences the migration of nutrients during maturation, which directly increases cell volume; ideal temperatures are close to $20^{\circ} \mathrm{C}$. During this study, the average temperature was $23.75^{\circ} \mathrm{C}$ in the first growing season and $23.55^{\circ} \mathrm{C}$ in the second (Figure 1). However, during the 2011/12 growing season, the maximum temperatures were often higher than the optimum, which might have caused interference in the nutrient translocation to the grape berries. This may have been responsible for the decrease in grape size during 2011/2012 growing seasons, except in Tempranillo, which was the least affected by these peaks in temperature, due to having a shorter cycle and being better adapted to regions with higher temperature ranges.

The $\mathrm{pH}$ progressively increased from veraison until harvest (Figure 4). However, the $\mathrm{pH}$ values obtained in the first growing season were greater than those values obtained in the second for all cultivars, and there were no significant differences between them (Table 1). All cultivars had a desirable $\mathrm{pH}$ in the 
second growing season, since according to Rizzon and Miele (2002) the recommended $\mathrm{pH}$ for must is a maximum of 3.30 to guarantee microbiological and physico-chemical stability. Wines with a $\mathrm{pH}$ greater than 3.5 are not sufficiently preserved since they allow harmful microbial flora to develop. The $\mathrm{pH}$ is extremely important in several aspects of wine production, such as growth and development of yeast and some fermentation mechanisms, and development of lactic bacteria, with $\mathrm{pH}$ being a requirement of malolactic fermentation. It is also a fundamental factor that influences the development of acetic bacteria as well as the activity of some pectolytic enzymes. Furthermore, $\mathrm{pH}$ determines the proportions of free and salified forms of each acid present in the wine.

Figure 4. Evolution of grape berries in $\mathrm{pH}$ during maturation of Cabernet Sauvignon (A), Merlot (B), Tempranillo (C), and Sangiovese (D) in Dois Vizinhos, PR during the 2008/2009 and 2011/2012 growing seasons. UTFPR Câmpus Pato Branco, 2012.
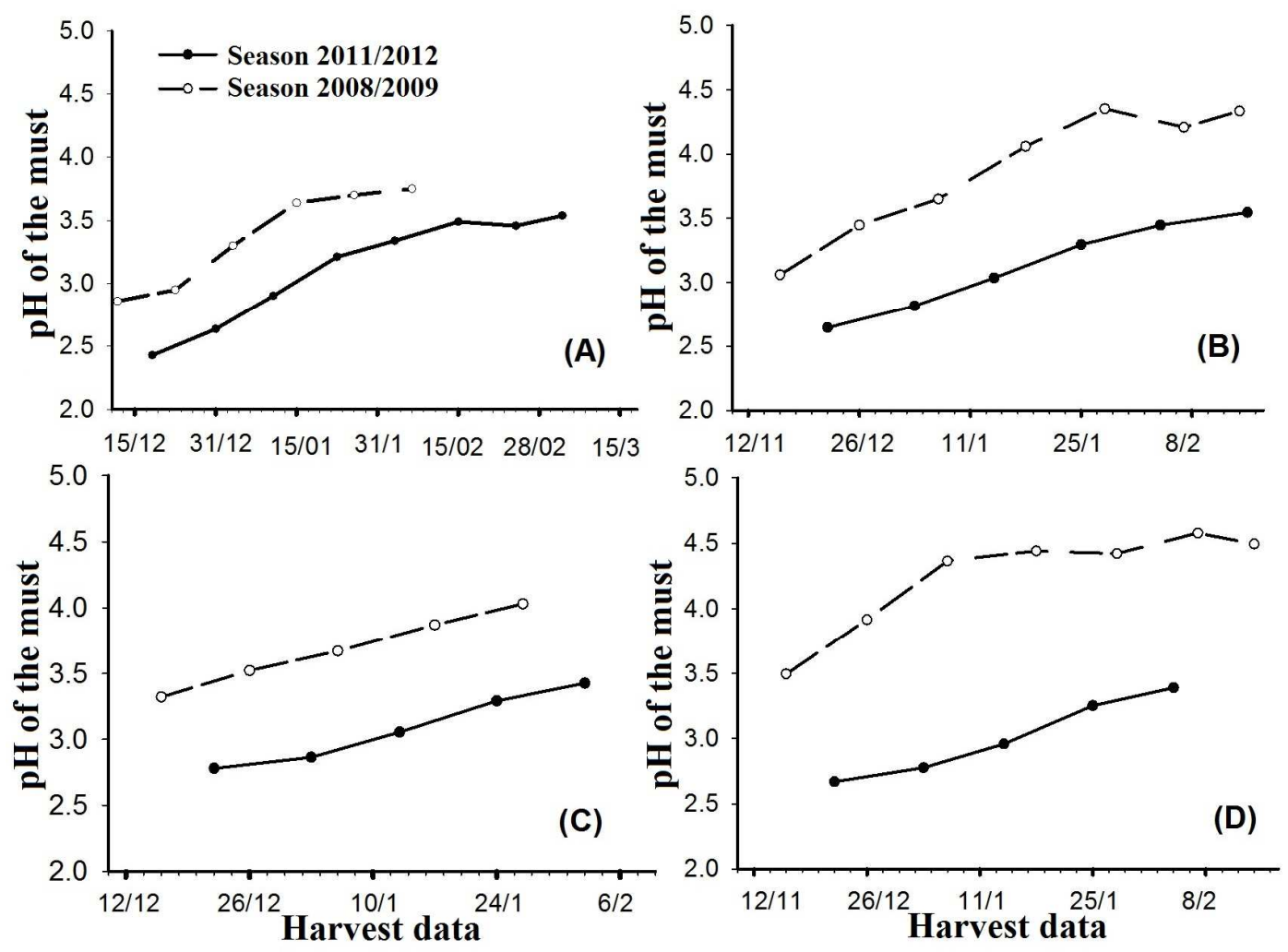

Source: Elaboration of the authors.

Where cultivars have a $\mathrm{pH}$ higher than the optimum, the $\mathrm{pH}$ levels can be reduce by defoliation around the flowering or bunches regions to create better light conditions. Studies carried out by Pötter et al. (2010) in several wine-growing areas showed that slightly defoliating the zone around the bunch of grapes in several phenological stages increased the total soluble solid content and decreased acidity, pH, and potassium (PÖTTER et al., 2010).
During the sampling dates, was observed for all cultivars an increase in total soluble solid content (Figure 5). The greatest TSS content was found in Merlot and Sangiovese in the 2008/2009 growing season, whilst there was no difference between Merlot and Tempranillo in the 2011/12 growing season. Cabernet Sauvignon during the 2008/2009 growing season had the lowest TSS content (Table 1). When compared to results from other studies, 
Merlot had a higher result than that obtained by Rizzon and Mielle (2003) who verified a content of $18.4{ }^{\circ}$ Brix. Sangiovese experienced a decrease in TSS content in the second growing season compared to the first; however, the results obtained were similar to those found by Intrieri et al. (2008) who obtained TSS values between 19.10 and $20.09^{\circ}$ Brix according to the different degrees of defoliation.

Figure 5. Evolution of Total Soluble Solids in grapes during the maturation of Cabernet Sauvignon (A), Merlot (B), Tempranillo (C), and Sangiovese (D) in Dois Vizinhos, PR during the 2008/2009 and 2011/2012 seasons. UTFPR Câmpus Pato Branco, 2012.
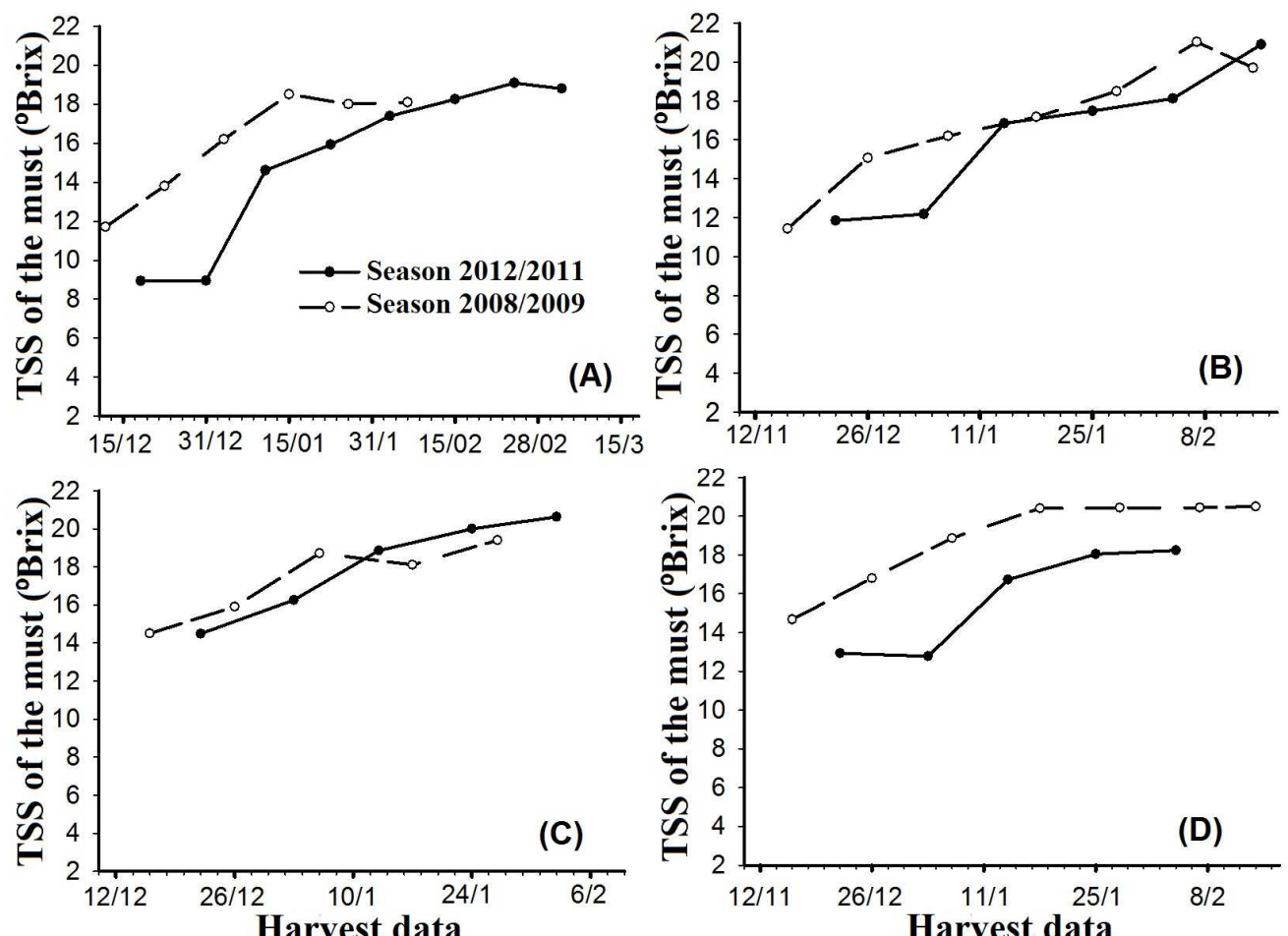

Source: Elaboration of the authors.

To obtain high sugar content, ideal temperatures during maturation are required, since high temperatures are capable of irreversibly altering the accumulation of sugar in the grapes (DIAS, 2006). As the second growing season received more rainfall than the first, there was consequently less sunlight and the maximum temperatures were high during this growing season, which caused results for Cabernet Sauvignon to differ from those found by other authors. Santos (2011) considers the best growing cycles to be those with summers that have little rainfall and days with ideal levels of sunlight to reach the desired total sugar levels of between 19.5 and $22^{\circ}$ Brix for this cultivar.
These TSS contents make all cultivars potentially capable of producing alcohol, up to the minimum requirement of $8.6 \%$ set by the legislation for fine table wines, without needing chaptalization of the must (BRASIL, 1998).

The TTA of all cultivars decreased during maturation (Figure 6). This decrease is due to the process of respiration of organic acids, and their dilution as the size of the grape berries increases, as well as salification (RIZZON; MIELE, 2003). For Dias (2006), during the crop growth phase the sugar produced gave rise to malic acid, which is stored in the cells of the grape berries and is reduced due to 
degradation during verasion. This enables the grape to obtain energy, since the consumption of sugar is inhibited, thereby reducing the acid content in the grape berries until maturation is complete.

Figure 6. Changes in the total acidity of grape must during maturation of grape cultivars Cabernet Sauvignon (A), Merlot (B), Tempranillo (C), and Sangiovese (D), in Dois Vizinhos, PR during the 2008/2009 and 2011/2012 growing seasons. UTFPR Câmpus Pato Branco, 2012.

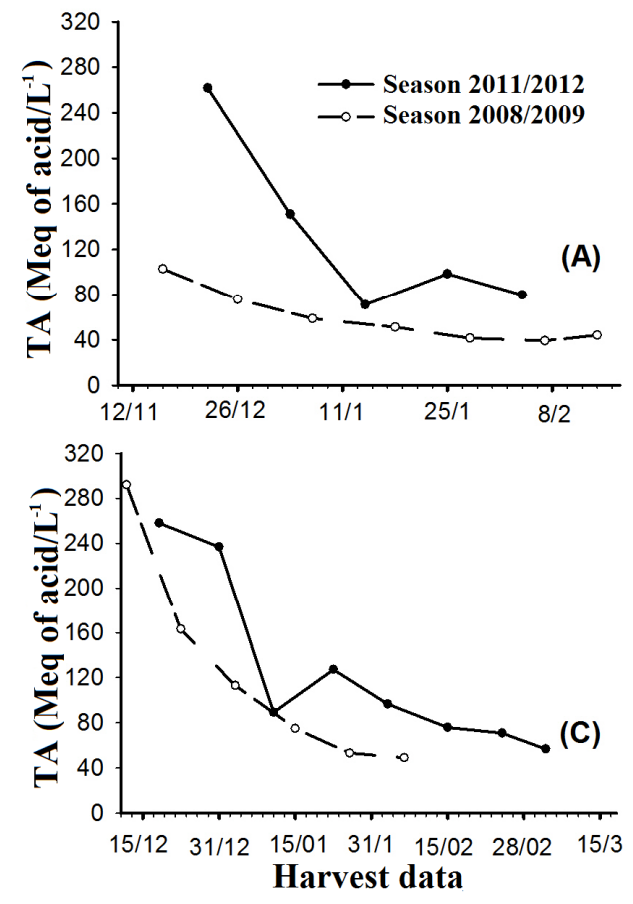

Source: Elaboration of the authors.

The highest TTA was found in the Sangiovese grapes at 79.51 meq $\mathrm{L}^{-1}$ of tartaric acid during the 2011/12 growing season, and the lowest was obtained by Merlot during the 2008/2009 growing season followed by Sangiovese and Cabernet Sauvignon. The highest TTA values occurred during the 2011/12 growing season (Table 1). The variation in TTA values from one growing season to another may be explained by greater rainfall during 2011/12 (2008/2009: 110 mm; 2011/2012: 434.2 mm, which was the total rainfall during sampling dates - Figure 1), since higher water availability increases the volume of the grape, thereby increasing the $\mathrm{pH}$ and TTA (DIAS, 2006).

Bevilaqua (1995) found that higher rainfall interfered with the acidity and sugar content of

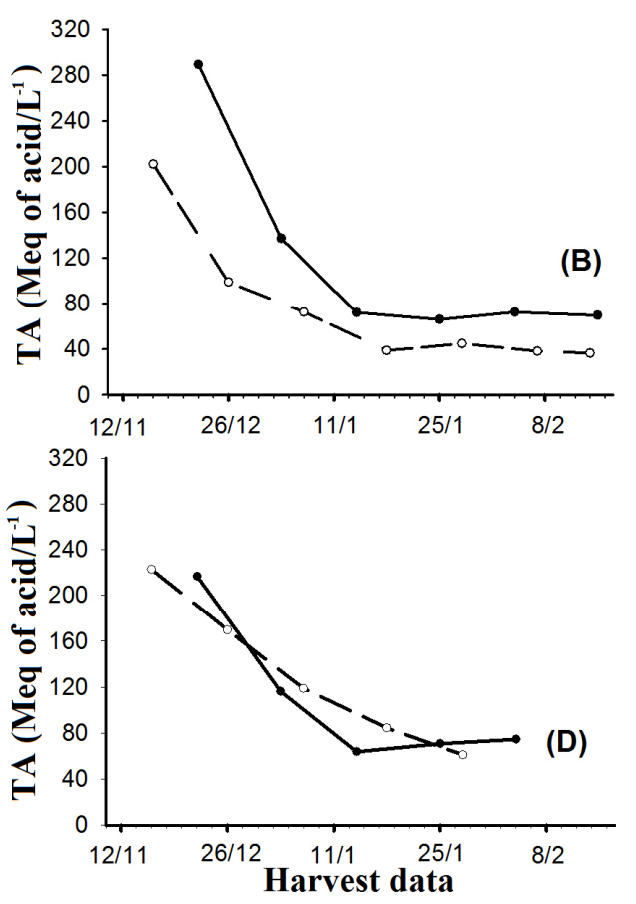

the must, causing a decrease in must quality, and consequently, in the wine. This, according to Dias (2006), together with higher maximum temperatures accelerates the degradation, primarily of malic acid, thereby decreasing the TTA. These factors are responsible for the large variations observed during the study seasons.

In the 2008/2009 growing seasons only Tempranillo met the total minimum acidity required by legislation for fine wine, which states a minimum acidity of 55.00 meq $\mathrm{L}^{-1}$. In the second growing season $(2011 / 2012)$, all cultivars met the minimum acidity content required by law (Table 1). The total acidity in must and wine is hugely important in enology, as it directly influences the organoleptic properties (taste, color, and smell), and 
the microbiological and physicochemical stability of wines (JACKSON, 2008).

The highest TSS/TTA ratio was observed for Merlot at 72.28 during the 2008/2009 growing season. In 2011/2012 growing season the ratio TSS/ TTA was lower than 2008/2009 growing season. The low TSS/TTA values obtained in that growing season may be due to the increase in total acidity of the grape berries in the vineyard studied, probably due to changes in rainfall during grape maturation. However, they were greater than the minimum values recommended, with approximately TSS/ TTA = 20 (CHOUDHURY, 2000).

Besides technological maturation, which is defined by soluble solid content and total acidity, phenolic maturation is an important tool when defining the maturation of red wines, as it helps determine the best time to harvest and the potential quality of the harvest or crop region (GUERRA; ZANUS, 2003).

The flavonols concentration in Cabernet Sauvignon, Merlot, and Tempranillo stabilized close to 31 January indicating degradation of these compounds and the start of over-ripening around this date (Figure 7). The best result was obtained by Cabernet Sauvignon, which had a mean flavonols concentration of $146.61 \mathrm{~g} \times 100 \mathrm{~g}^{-1}$ of peel (Table 1). For all cultivars, the higher contents of flavonols were obtained in the 2008/2009 growing season.

For the concentration of anthocyanins, Tempranillo and Cabernet Sauvignon showed the best results, 388.99 and $344.36 \mathrm{mg} 100 \mathrm{~g}^{-1}$ of peel, respectively, both during the 2008/2009 season (Table 1). The growing season had no influence on this characteristic in Sangiovese (Figure 8).

Figure 7. Changes in the flavonoid concentration during maturation of Cabernet Sauvignon (A), Merlot (B), Tempranillo (C), and Sangiovese (D) grapes berries during the 2008/2009 and 2011/12 growing seasons. UTFPR Câmpus Pato Branco, 2012.
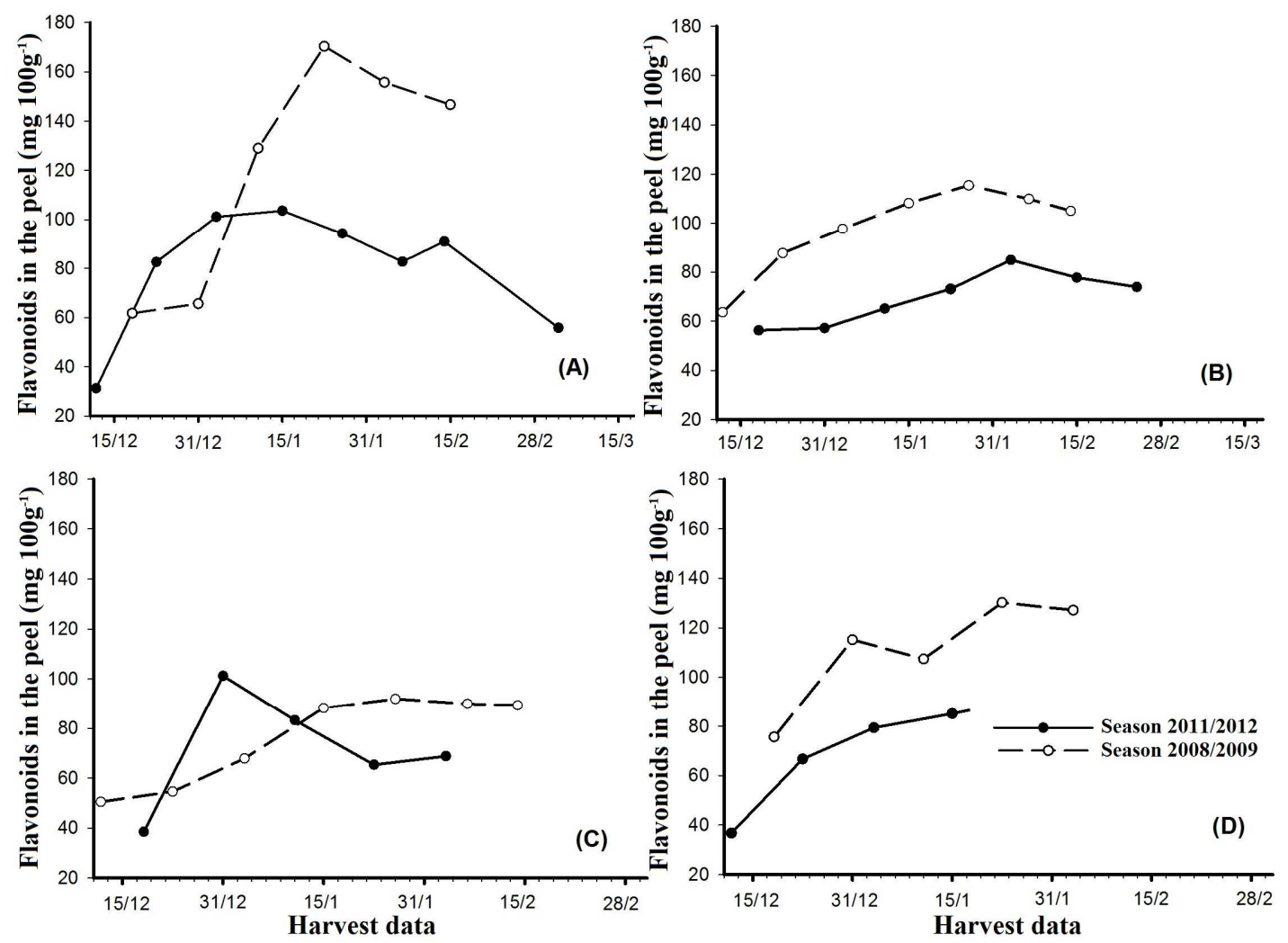

Source: Elaboration of the authors. 
Figure 8. Changes in the anthocyanin concentration during maturation of Cabernet Sauvignon (A), Merlot (B), Tempranillo (C), and Sangiovese (D) grapes berries. UTFPR Câmpus Pato Branco, 2012.
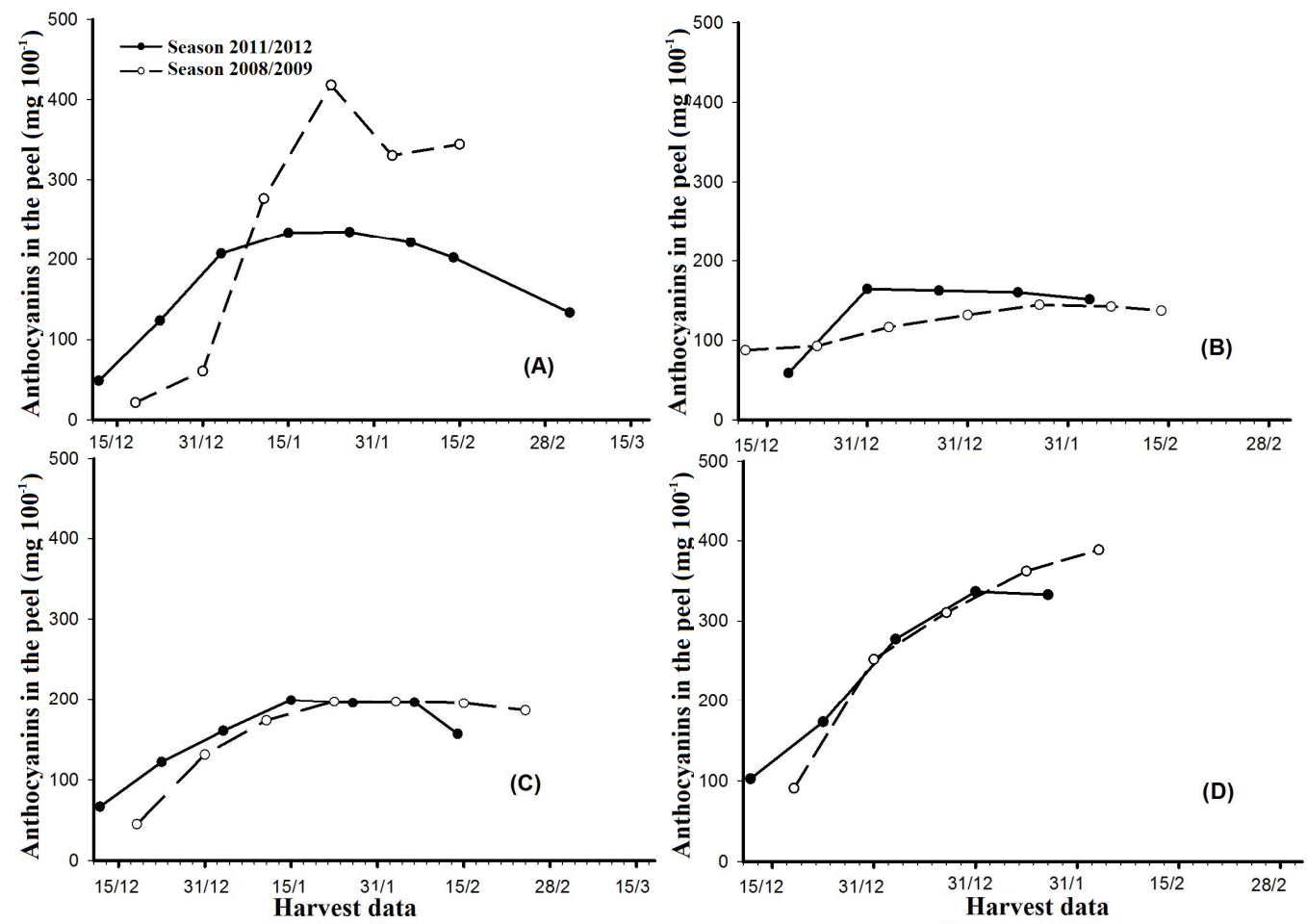

Source: Elaboration of the authors.

In red wines, the anthocyanins represent the highest percentage of phenolic compounds, making it an important constituent in the production of red wines since it contributes to sensory characteristics, in particular the color of the wine (MUÑOZESPADA et al., 2004).

According to Hernández-Hierro (2012), the biosynthesis and accumulation of anthocyanins in grape peel occur at the start of veraison, with maximum accumulation occurring close to harvest; however, there is a decrease in anthocyanin content during over-ripening. The decrease in anthocyanin content after this period occurs due to changes in environmental conditions and management techniques during maturation (RYAN; REVILLA, 2003). According to Dias (2006), higher temperatures influence the content of phenolic compounds, thereby decreasing, for example, the anthocyanin content.
The anthocyanin content is $\mathrm{pH}$ dependent. The $\mathrm{pH}$ change causes modifications in the structure of anthocyanins which are in equilibrium in the solution, and this changes the coloring of wine (BROUILLARD, 1982). This could explain, in part, the lower concentration of anthocyanins in the second growing season.

The wines must meet minimum quality standards required by legislation. In this sense, it is interesting to note that all cultivars met Brazilian's standards of identity and quality established by the Ministério da Agricultura e Abastecimento for fine dry red wines.

\section{Conclusions}

All cultivars did not have enough total acidity to give the wine the desired stability for long-term storage, making this ideal to be consumed as young wine. Only in the second year the acidity reach 
adequate values, according to the standards set by the Ministério da Agricultura e do Abastecimento of Brazil (MAPA).

All the cultivars had good sugar content and did not require chaptalization of the must, and the alcohol content was within the limit prescribe in the established guidelines of MAPA.

Tempranillo grapes showed the best maturation with regard to physico-chemical attributes during the growing seasons when they were sampled, demonstrating that it was the cultivar best adapted to the environment studied.

\section{References}

BEVILAQUA, G. P. Avaliações físico-químicas durante a maturação de videiras cultivadas no Rio Grande do Sul. Revista Brasileira de Agrociências, Pelotas, v. 1, n. 3, p. 151-156, 1995.

BHERING, S. B.; SANTOS, H. G.; BOGNOLA, I. A.; CÚRCIO, G. R.; MANZATTO, C. V.; CARVALHO, J. W.; CHAGAS, C. S.; ÁGLIO, M. L. D.; SOUZA, J. S. Mapa de solos do Estado do Paraná: legenda atualizada. Rio de Janeiro: EMBRAPA/IAPAR, 2008. 74 p.

BRASIL. Ministério da Agricultura, Pecuária e Abastecimento. Portaria $\mathrm{n}^{\circ}$. 283, de 18 de junho de 1998. Aprova normas e procedimentos para o registro de estabelecimento, bebidas e vinagres, inclusive vinhos e derivados da uva e do vinho e expedição dos respectivos certificados. Diário Oficial [da] República Federativa do Brasil, Brasília, DF, 22 jun. 1998. Seção 1, n. 106.

BROUILLARD, R. Anthocyanins as food colors. Chemical structure of anthocyanins. In: MARKAKIS, P. (Ed.). Food science and technology. New York: Academic Press, 1982. cap. 1, p. 1-39.

CAVIGLIONE, J. H.; KIIHL, L. R. B.; CARAMORI, P. H.; OLIVEIRA, D. Cartas climáticas do Paraná. Londrina: IAPAR, 2000.

CHOUDHURY, M. M. A Viticultura no semiárido brasileiro. Colheita, manuseio pós-colheita e qualidade mercadológica de uvas de mesa. Fortaleza: EMBRAPA SEMI-ÁRIDO, 2000. cap. 13, 366 p.

CONDE, C.; SILVA, P.; FONTES, N.; DIAS, A. C. P.; TAVARES, R. M.; SOUSA, M. J.; AGASSE, A.; DELROT, S.; GERÓS, H. Biochemical changes throughout grape berry development and fruit and wine quality. Food, Braga, v. 1, n. 1, p. 1-22, 2007.
CRUZ, C. D. Programa genes (versão windows): aplicativo computacional em genética e estatística. Viçosa: UFV, 2013. 648 p.

DIAS, J. P. Fases da maturação da uva. Centésimo curso intensivo de vinificação. Ministério da Agricultura do Desenvolvimento Rural e das Pescas, Brasília, 2006. p. $1-8$.

GIL, G. F.; PSZCZÓLKOWSKI, P. Viticultura: fundamentos para optimizar producción y calidad. Santiago: Ediciones Universidad Católica de Chile, 2007. $535 \mathrm{p}$.

GUERRA, C. C.; ZANUS, M. C. Uvas viníferas para processamento em regiões de clima temperado. maturação e colheita. Bento Gonçalves: Embrapa Uva e Vinho, jul. 2003. Disponível em: <http:// sistemasdeproducao.cnptia.embrapa.br/FontesHTML/ Uva/UvasViniferasRegioesClimaTemperado/cultivar. htm>. Acesso em: 12 mar. 2013.

HERNÁNDEZ-HIERRO, J. M.; QUIJADA-MORÍN, N.; RIVAS-GONZALO, J. C.; ESCRIBANO-BAILÓN, M. T. Influence of the physiological stage and the content of soluble solids on the anthocyanin extractbility of Vitis vinifera L. cv. Tempranillo grapes. Analytica Chimica Acta, Salacama, v. 732, n. 1, p. 26-32, 2012.

INSTITUTO BRASILEIRO DE GEOGRAFIA E ESTATÍSTICA - IBGE. Produção e comercialização de uvas e vinhos: panorama 2013. Levantamento Sistemático da Produção Agrícola, 2013. Disponível em: $<$ http://www.ibge.gov.br/home/estatistica/indicadores/ agropecuaria/lspa/lspa_201304.pdf $>$. Acesso em: 23 jun. 2013.

INTRIERI， C.; FILIPETTI， I.; ALLEGRO, G.; CENTINARI, M.; PONI, S. Early defoliation (hand vs mechanical) for improved crop control and grape composition in Sangiovese (Vitis vinifera L.). Australian Journal of Grape and Wine Research, Adelaide, v. 14, n. 1, p. 25-32, 2008.

INSTITUTO ADOLFO LUTZ - IAL. Métodos físicoquímicos para análise de alimentos. 4. ed. São Paulo: IMESP, 2008. $78 \mathrm{p}$.

JACKSON, R. Chemical constituents of grapes. In: Wine science: principles and applications. London: Academic Press, 2008. v. 3, cap. 6, p. 270-331.

JAULMES, P.; ESPEZEL, P. Le dosage de l'acetaldehyde dans les vins et les spiritueux. Ann. Falsif., Paris, v. 28, n. 1, p. 325-335, 1935.

LEES, D. H.; FRANCIS, F. J. Standartization of pigment analyzes in cranberries. HortScience, Alexandria, v. 7, n. 1, p. 83-84, 1972. 
MUÑOZ-ESPADA, A. C.; WOOD, K. V.; BORDELON, B.; WATKINS, B. A. Anthocyanin quantification and radical scavenging capacity of Concord, Norton, and Marechal Foch Grapes and wines. Journal of Agricultural and Food Chemistry, Washington, v. 52, n. 22, p. 67796786, 2004.

PÖTTER, G. H.; DAUDT, C. E.; BRACKMANN, A.; LEITE, T. T.; PENNA, N. G. Desfolha parcial em videiras e seus efeitos em uvas e vinhos Cabernet Sauvignon da região da Campanha do Rio Grande do Sul, Brasil. Ciência Rural, Santa Maria, v. 40, n. 9, p. 2011-2016, 2010.

RIZZON, L. A.; MIELE, A. Acidez na vinificação em tinto das uvas Isabel, Cabernet Sauvignon e Cabernet Franc. Ciência Rural, Santa Maria, v. 32, n. 3, p. 511$515,2002$.

Avaliação da cv. Merlot para elaboração de vinho tinto. Ciência e Tecnologia de Alimentos, Campinas, v. 23, p. 156-161, 2003. Suplemento.

RYAN, J. M.; REVILLA, E. Anthocyanin composition of cabernet sauvignon and tempranillo grapes at different stages of ripening. Journal of Agriculture and food Chemistry, Washington, v. 51, n. 11, p. 3372-3378, 2003.
SANTOS, M. Analise cromática de vinhos tintos da variedade Cabernet Sauvignon do Rio Grande do Sul. 2011. Dissertação (Mestrado em Ciências e Tecnologia de Alimentos) - Universidade Federal de Santa Maria, Santa Maria.

SATO, A. J.; ROBERTO, S. R. A viticultura no Paraná. Departamento de Agronomia, Universidade Estadual de Londrina, 2008. Disponível em: <http://www.uepg. br/uepg_departamentos/defito/htm/labiovegetal/A_ Viticultura_No_Parana.pdf>. Acesso em: 08 mar. 2013.

SECRETARIA DA AGRICULTURA E DO ABASTECIMENTO DO ESTADO DO PARANÁ SEAB/DERAL. Área e produção de frutas por região administrativa da SEAB de 2007-2011. 2011. Disponível em: $\quad<$ http://www.agricultura.pr.gov.br/arquivos/File/ deral/fru5.pdf>. Acesso em: 20 jun. 2013.

ZSÓFI, Z.; TÓTH, E.; RUSJAN, D.; BÁLO, B. Terroir aspects of grape quality in a cool climate wine region: relationship between water deficit, vegetative growth and berry sugar concentration. Scientia Horticulturae, Alexandria, v. 127, n. 4, p. 494-499, 2009. 
